\title{
Induksi Mutasi Curcuma zedoaria (Christm) Roscoe dengan Irradiasi Sinar Gamma
}

\author{
Induced Mutation of Curcuma zedoaria (Christm) Roscoe using Gamma Rays Irradiation
}

\author{
Yuyu Suryasari Poerba* dan Diah Martanti
}

Bidang Botani, Puslit Biologi LIPI, Cibinong Science Center, Jl. Raya Bogor Km 46.5 Cibinong Bogor 16911

E-mail: yyspoerba@yahoo.com*Penulis untuk korespondensi

\begin{abstract}
Curcuma zedoaria (Zingiberaceae) is one of Curcuma spp. used as stomachic, carminative, haematic and styptic medicines. Dried rhizomes of $C$. zedoaria contain essential oil and curcuminoids. Induced mutation of this species would provide and help plant breeders to improve and select better quality of the plant. The present study was carried out to determine LD-50\% of gamma irradiation of $C$. zedoaria, to induce genetic variation using gamma irradiation, and to assess genetic diversity among mutant genotypes using random amplified polymorphic DNA (RAPD) markers. The LD-50\% of gamma irradiation was achieved at 813.32 rad. Chlorophyll mutations were recorded at vM1 and vM2. Result of genetic analysis showed that RAPD profiles were different from that of the control, and genetic dissimilarities among mutant genotypes were higher than that of the control.
\end{abstract}

Key words: Curcuma zedoaria, random amplified polymorphic DNA, genetic variation, gamma irradiation

Diterima: 23 September 2008, disetujui: 03 Maret 2009

\section{Pendahuluan}

Temu putih atau kunir putih (Curcuma zedoaria) merupakan salah satu jenis tumbuhan bahan obat yang banyak tumbuh meliar di daerah Jawa Barat dan Jawa Tengah hingga ketinggian $1000 \mathrm{~m}$ dpl. Nama lain tumbuhan (sinonim) adalah Curcuma pallida Lour, Curcuma zerumbet Roxb. Tumbuhan ini berupa semak, batang semu dengan 6-8 helai pelepah daun yang berpadu, tumbuh tegak lurus, dan berumbi akar (rimpang). Seperti pada jenis Curcuma lainnya, rimpang C. zedoaria banyak digunakan sebagai stimulan, diuretik, antipiretik dan anti emetic. Rimpang C. zedoaria mengandung $1.5 \%$ minyak atsiri, curcuminoid dan turunannya (Wardini dan Prakoso, 1999).

Curcuma zedoaria merupakan tanaman triploid dengan jumlah kromosom $2 n=63,64$, 66 Program perbaikan genetik secara konvensional $C$. zedoaria mengalami hambatan karena rendahnya fertilitas polen dan rendahnya pembentukan biji (Wardini dan Parkoso, 1999).

Induksi mutasi sangat efektif dalam memperluas keragaman genetik sehingga sumber daya genetik tersedia dalam upaya perbaikan tanaman seperti serealia, buahbuahan dan tanaman lainnya (Lee et al., 2002). Pemuliaan mutasi telah menghasilkan lebih dari 2250 varietas tanaman (Maluszynski et al., 2000); Ahloowalia et al., (2004). 70\% dari varietas ini dilepas langsung sebagai mutan yang diinduksi dan sisanya $30 \%$ disilangkan dengan mutan yang diinduksi (Schouten dan Jacobsen, 2007). Metode mutagenesis bervariasi dalam frekuensi mutan, spektrum, keuntungan dalam skrining dan penggunaannya. Untuk mutagen fisik, sinar X, sinar gamma dan neutron cepat seringkali digunakan untuk menginduksi mutasi. Sinar gamma sangat sering (64\%) digunakan untuk 
menginduksi mutasi, diikuti oleh sinar X (22\%) (Ahloowalia et al., 2004).

Irradiasi sinar gamma sebagai mutagen dapat menginduksi mutasi baik yang merugikan maupun mutasi yang menguntungkan. Beberapa mutan menguntungkan seperti pada kacang hijau yang diperlakukan dengan sinar gamma, berat kering meningkat, kandungan klorofil meningkat (Sangsiri et al., 2005). Variasi dalam karakter kuantitatif yang diinduksi oleh mutasi juga dilaporkan seperti hasil tanaman, ukuran biji, jumlah biji per polong, umur tanaman, tinggi tanaman juga ketahanan terhadap penyakit (Sangsiri et al., 2005). Perubahan genetik karena kerusakan DNA, akibat irradiasi gamma ini dapat dideteksi dengan marka Random Amplified Polymorphic DNA (RAPD) seperti pada bunga matahari dan anggur (Selvi et al., 2007).

Penelitian ini bertujuan untuk menginduksi keragaman genetik $C$. zedoaria dengan menggunakan radiasi sinar gamma untuk menghasilkan populasi mutan yang bervariasi dan dapat diseleksi lebih lanjut dalam menghasilkan varian baru yang lebih unggul. Diharapkan hasil dari penelitian ini dapat diperoleh informasi $\mathrm{LD}-50 \%$ radiasi gamma pada $C$. zedoaria dan meningkatnya variasi genetik dari populasi mutan, dan teridentifikasinya genotipe mutan berdasarkan marka RAPD.

\section{Metode Penelitian}

Potongan rimpang C. zedoaria dengan 23 mata tunas di radiasi dengan sinar Gamma (sumber Cobalt-60 dalam Gamma chamber 4000A) dengan berbagai dosis $(0,300 \mathrm{rad}, 600$ $\mathrm{rad}, 900 \mathrm{rad}, 1200 \mathrm{rad}$ dan $1500 \mathrm{rad}$ ) di Pusat
Aplikasi Isotop dan Radiasi, BATAN. Selanjutnya, potongan rimpang tersebut ditanaman dalam bak-bak perkecambahan yang berisi media pasir:tanah:kompos (1:1:1). Setelah satu bulan, bibit $C$. zedoaria ditanam dalam polybag yang berisi media kompos: tanah: pasir (1:1:1) dan ditempatkan di rumah kaca. Parameter yang diteliti yaitu survival tanaman (\%), mutasi klorofil, pertumbuhan vegetatif tanaman yang meliputi tinggi tanaman (cm), jumlah daun, serta abnormalitas tanaman hasil induksi mutasi. Tanaman $\mathrm{vM}_{1}$ dipanen umbinya untuk ditanam lebih lanjut untuk menghasilkan sekitar populasi tanaman $\mathrm{vM}_{2}$. Seleksi individu tanaman berdasarkan variasi fenotipik dimulai pada populasi $\mathrm{vM}_{2}$ dengan fokus karakter agronomi dan hasil tanaman. Hasil tanaman dan komponen hasil digunakan sebagai kriteria seleksi. Sejumlah 150 tanaman yang diseleksi kemudian ditanam di lapangan untuk perbanyakan tanaman.

Analisis untuk mengkonfirmasi mutasi genetik berdasarkan RAPD dilakukan. Material DNA C. zedoaria hasil induksi mutasi pada generasi $\mathrm{vM}_{2}$ berupa potongan daun muda yang dikeringkan dengan silika gel dikoleksi dan selanjutnya dianalisis. Ekstraksi DNA dilakukan dengan menggunakan metode Cetyl Trimethyl Ammonium Bromide (CTAB) yang dimodifikasi (Delaporta et al., 1983), yaitu dengan penambahan RNase dengan konsentrasi akhir $250 \mu \mathrm{g} / \mathrm{mL}$. Amplifikasi DNA dilakukan berdasarkan metode Williams et al., (1990) dengan menggunakan 4 'arbitrary' primer RAPD terpilih, yaitu OPA-07, OPA-19, OPC07 dan OPD-04 (Operon Technology Ltd) (Tabel 1), yang merupakan primer yang menghasilkan pita polimorfik dan sebelumnya diuji pada C. zedoaria (Poerba, 2007).

Tabel 1. Primer yang digunakan dan jumlah pita DNA hasil amplifikasi pada 12 sampel Curcuma zedoaria (Christm) Roscoe kontrol.

\begin{tabular}{ccccc}
\hline \hline Kode Primer & Urutan Basa & Jumlah Fragmen & Poli Morfik & Ukuran fragmen DNA \\
\hline \hline OPA-11 & CAATCGCCGT & 11 & 2 & $200 \mathrm{bp}-3.0 \mathrm{~kb}$ \\
OPA-19 & CAAACGTCGG & 8 & 1 & $350 \mathrm{bp}-2.0 \mathrm{~kb}$ \\
OPB-07 & GGTGACGCAG & 11 & 2 & $250 \mathrm{bp}-2.0 \mathrm{~kb}$ \\
OPC-06 & GAACGGACTC & 6 & 2 & $300 \mathrm{bp}-1 \mathrm{~kb}$ \\
OPC-16 & CACACTCCAG & 5 & 0 & $300 \mathrm{bp}-1.5 \mathrm{~kb}$ \\
OPD-04 & TCTGGTGAGG & 10 & 5 & $450 \mathrm{bp}-1.8 \mathrm{~kb}$ \\
OPD-13 & GGGGTGACGA & 11 & 2 & $200 \mathrm{bp}-1.8 \mathrm{~kb}$ \\
\hline \hline
\end{tabular}


Reaksi PCR dilakukan pada volume total $15 \mu \mathrm{l}$ yang berisi $0.2 \mathrm{nM}$ dNTPs; $1 \mathrm{X}$ bufer reaksi; $2 \mathrm{mM} \mathrm{MgCl}_{2} ; 25 \mathrm{ng}$ DNA sample; 1 pmole primer tunggal; dan 1 unit Taq DNA polymerase (Promega) dengan menggunakan Thermocylcer (Takara) selama 45 siklus. Pemanasan pertama pada suhu $94^{\circ} \mathrm{C}$ selama 2 menit, kemudian diikuti oleh 45 siklus yang terdiri atas denaturasi 1 menit pada suhu $94^{\circ} \mathrm{C}$, annealing 1 menit pada suhu $36^{\circ} \mathrm{C}$, dan 2 menit ektensi pada suhu $72^{\circ} \mathrm{C}$. Setelah 45 siklus selesai, kemudian diikuti 5 menit proses ekstensi fragmen DNA pada suhu $72^{\circ} \mathrm{C}$ dan pendinginan pada suhu $25^{\circ} \mathrm{C}$. Hasil amplifikasi PCR divisualisasi pada gel agarosa $2.0 \%$ dalam bufer TEA (Tris-EDTA) secara elektroforesis dengan menggunakan Mupid Mini Cell selama 50 menit pada 50 Volt. Kemudian direndam dalam larutan ethidium bromida dengan konsentrasi akhir $1 \mu \mathrm{l} / 100 \mathrm{ml}$ selama 10 menit.

Hasil pemisahan fragmen DNA dideteksi dengan menggunakan UV transluminator, kemudian difoto dengan menggunakan kamera polaroid. Sebagai standar ukuran DNA digunakan 100 bp DNA ladder (Promega) untuk menetapkan ukuran pita hasil amplifikasi DNA.

Karena RAPD merupakan marka yang dominan, maka setiap pita RAPD dianggap sebagai satu lokus putatif bialel (single biallelic locus) (Williams et al., 1990). Hanya lokus yang menunjukkan pita yang jelas yang digunakan untuk skoring: ada (1) dan kosong (0). Nilai kesamaan genetika diambil dari Simple Matching Coefficient (Dunn dan Everitt, 1982; Rohlf, 1997), sedangkan nilai ketidaksamaan genetik merupakan pengurangan nilai dalam matrik kemiripan oleh nilai 1 (Dunn dan Everitt, 1982).

\section{Hasil dan Pembahasan}

\section{Generasi pertama setelah perlakuan radiasi $\operatorname{gamma}\left(\mathbf{v M}_{1}\right)$}

Pengaruh visual dari radiasi gamma pada C. zedoaria pada generasi $\mathrm{vM}_{1}$ terlihat seperti terlihat pada Gambar 1, yaitu defisiensi khlorofil berupa garis putih memanjang sepanjang daun atau berupa bercak-bercak putih pada daun atau bagian daun yang menguning atau memutih, bahkan ada yang albino.

Radiasi gamma juga berpengaruh terhadap pertumbuhan tanaman. Tinggi tanaman, jumlah daun panjang dan lebar daun cenderung menurun sejalan dengan meningkatnya radiasi gamma, kecuali padfa dosis radiasi gamma yang rendah (300 rad) (Gambar 2). Hasil penelitian pendahuluan menunjukkan bahwa dosis radiasi gamma yang digunakan $(0,300 \mathrm{rad}, 600 \mathrm{rad}, 900 \mathrm{rad}, 1200$ rad dan $1500 \mathrm{rad}$ ) berpengaruh nyata terhadap survival tanaman setelah 10 bulan perlakuan. Dosis radiasi diatas 1200 rad menyebabkan semua tanaman mati hingga $100 \%$.

Hasil penelitian nilai LD-50 dicapai pada dosis 813.82 rad (Gambar 3). Oleh karenanya untuk penelitian selanjutnya dosis radiasi gamma 600 dan 900 rad difokuskan untuk diseleksi lebih lanjut. Sejumlah 100 tanaman dari dosis radiasi tersebut ditanam selanjutnya $\mathrm{vM}_{2}$ untuk seleksi lebih lanjut.

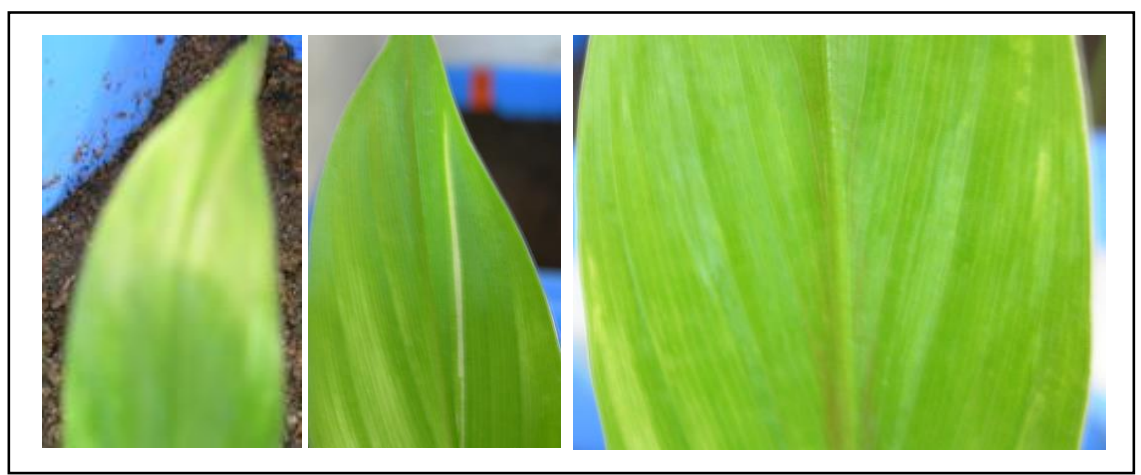

Gambar 1. Penampilan defisiensi klorofil pada Curcuma zedoaria (Christm) Roscoe pada generasi pertama setelah perlakuan radiasi gamma $\left(\mathrm{vM}_{1}\right)$. 


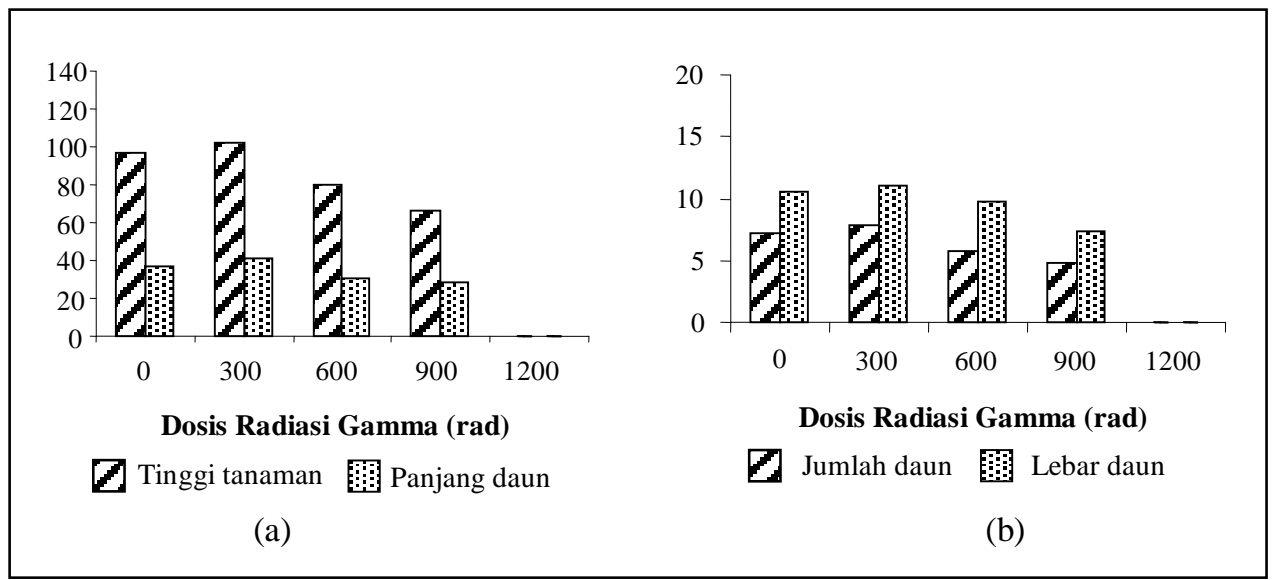

Gambar 2. Pengaruh radiasi gamma terhadap tinggi tanaman dan panjang daun (a) serta terhadap jumlah dan lebar daun (b) Curcuma zedoaria (Christm) Roscoe pada generasi pertama setelah perlakuan $\left(\mathrm{vM}_{1}\right)$.

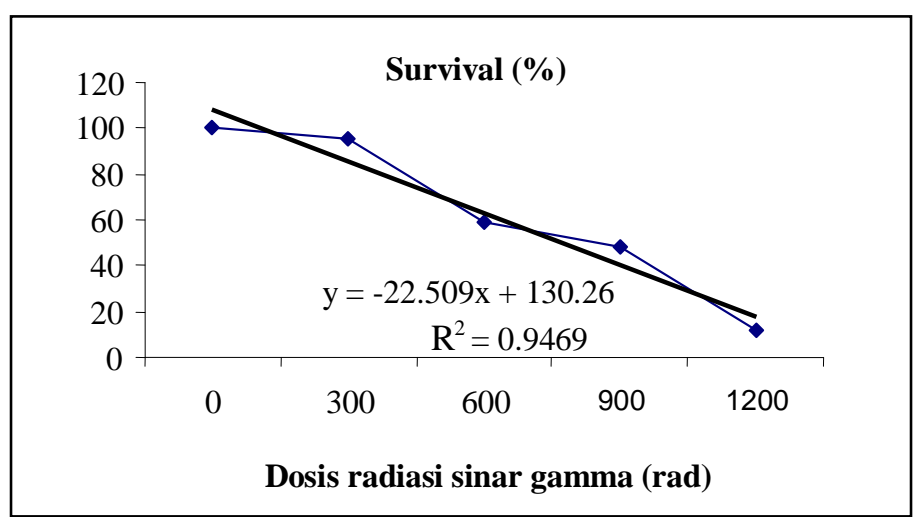

Gambar 3. Pengaruh sinar gamma terhadap survival tanaman Curcuma zedoaria (Christm) Roscoe pada generasi pertama setelah perlakuan $\left(\mathrm{vM}_{1}\right)$.

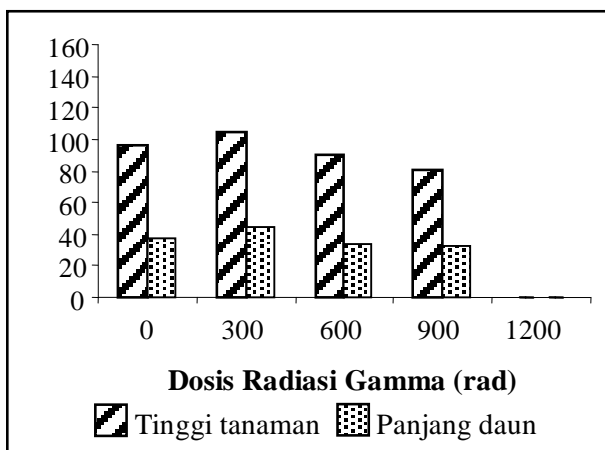

(a)

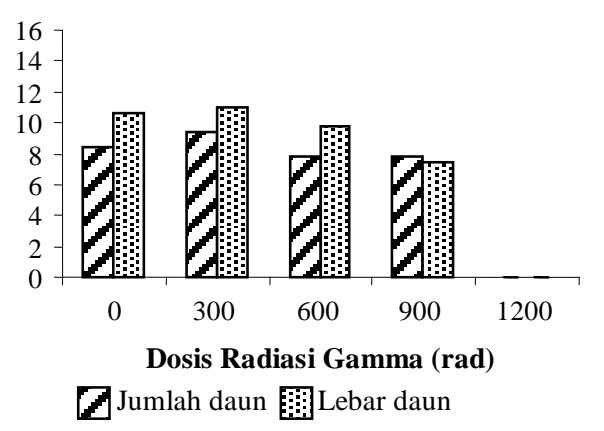

(b)

Gambar 4. Pengaruh radiasi gamma terhadap tinggi tanaman dan panjang daun (a) serta terhadap jumlah dan lebar daun (b) Curcuma zedoaria (Christm) Roscoe pada generasi kedua setelah perlakuan $\left(\mathrm{vM}_{2}\right)$. 


\section{Generasi kedua setelah perlakuan radiasi gamma $\left(\mathbf{v M}_{2}\right)$}

Pada generasi $\mathrm{vM}_{2}$ ini, seluruh genotipe hasil radiasi ditanam dan diperbanyak untuk dievaluasi karakter agromonisnya. Pengaruh radiasi gamma terhadap pertumbuhan vegetatif C. zedoaria pada generasi $\mathrm{vM}_{2}$ pada terlihat pada Gambar 4.

Pada umumnya, semua karakter agronomi yang diamati cenderung menurun, kecuali pada dosis radiasi rendah (300 rad), yang memiliki penampilan lebih tinggi dibanding kontrolnya. Dari hasil mutagenesis ini, $0.15 \%$ tanaman vM2 mengalami defisiensi klorofil.

\section{Identifikasi genetik mutan C. Zedoaria}

\section{Analisis Profil RAPD}

Hasil amplifikasi total genom DNA dengan menggunakan empat primer acak pada 20 mutan $C$. zedoaria dan tujuh primer pada kontrol menghasilkan produk PCR yang dapat dibaca dan diskor, sehingga hasilnya dapat dianalisis (Gambar 5). Sekuens dari kedua primer ini dan jumlah marka RAPD yang dihasilkan tertera pada Tabel 1 dan Tabel 2.

Pola pita DNA hasil elektroforesis menunjukkan bahwa setiap jenis primer menghasilkan pola pita-DNA yang berbeda pada setiap sampel. Hasil pengamatan menunjukkan bahwa diperoleh 72 fragmen DNA yang berukuran dari $160 \mathrm{bp}$ hingga 2.6 kb. Dari 92 fragmen DNA, 71 (98.61\%) merupakan fragmen polimorfik. Primer OPA07 menghasilkan pita polimorfik tertinggi dengan 23 pita (Tabel 2). Sedangkan pada tanaman kontrol, dengan menggunkan lebih banyak primer, dari 62 pita DNA total, hanya $22.58 \%$ merupakan pita DNA polimorfik (Tabel 1).

Hasil pengamatan terhadap pola pita DNA menunjukkan adanya pita DNA yang tidak muncul dibandingkan dengan kontrolnya. Pada primer OPA-19 pita-pita DNA yang tidak muncul cukup banyak (Gambar 5), yang menunjukkan adanya large-scale deletion. Hasil pengamatan terhadap nilai ketidaksamaan genetik pada genotipe hasil mutasi menunjukkan kisaran antara $0.35-0.75$, sedangkan kontrol berkisar antara $0.02-0.07$.

Tabel 2. Primer yang digunakan dan jumlah pita DNA hasil amplifikasi pada 20 sampel Curcuma zedoaria (Christm) Roscoe hasil induksi mutasi pada generasi $\mathrm{vM}_{3}$.

\begin{tabular}{lcccc}
\hline \hline Kode Primer & Urutan Basa & Jumlah Fragmen & Poli Morfik & Ukuran fragmen DNA \\
\hline \hline OPA-07 & CAATCGCCGT & 23 & 23 & $200 \mathrm{bp}-2.6 \mathrm{~kb}$ \\
OPA-19 & CAAACGTCGG & 8 & 8 & $200 \mathrm{bp}-900 \mathrm{bp}$ \\
OPB-07 & GGTGACGCAG & 21 & 20 & $160 \mathrm{bp}-2.5 \mathrm{~kb}$ \\
OPD-04 & TCTGGTGAGG & 20 & 20 & $300 \mathrm{bp}-2.5 \mathrm{~kb}$ \\
\hline \hline & Jumlah & 72 & $71(98.61 \%)$ & \\
\hline \hline
\end{tabular}

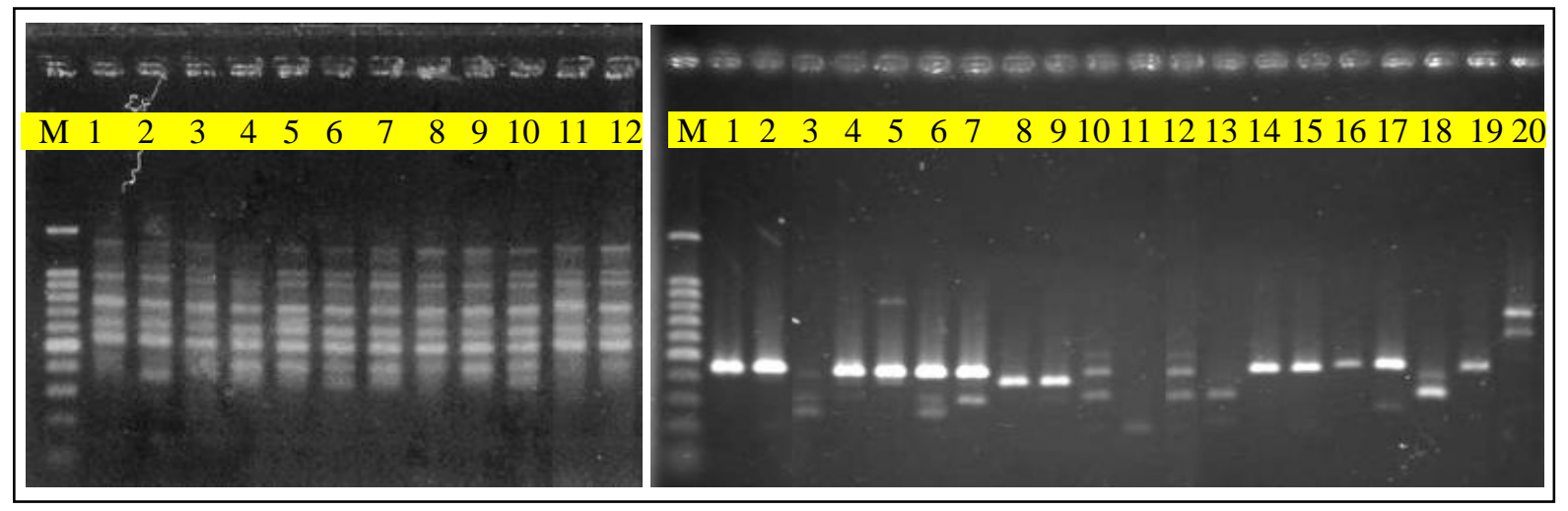

Gambar 5. Hasil amplikasi Curcuma zedoaria (Christm) Roscoe hasil induksi mutasi (kanan) dan kontrolnya (kiri) dengan primer OPA-19. 
Mutagenesis dengan iradiasi sinar gamma dapat mengakibatkan mutasi fenotipik yang berat berupa delesi skala besar dan kadang-kadang rekonstitusi kromosom (Matsukura et al., 2007). Selain itu, dosis sinar gamma sedang dan rendah menyebabkan mutan yang berguna relatif tinggi dengan sifatsifat daya hasil normal (Dumanovic et al., 1968). Sinar gamma sangat berperan dalam menginduksi perubahan genetik dalam DNA pada berbagai tanaman. Sinar gamma sangat berperan dalam menginduksi perubahan genetik dalam DNA pada berbagai tanaman.

Pada generasi pertama setelah perlakuan radiasi $\left(\mathrm{vM}_{1}\right)$ terlihat bahwa adanya kecenderungan semakin tinggi dosis radiasi sinar gamma, pertumbuhan tanaman semakin menurun kecuali pada dosis sinar gamma rendah (300 rad), yang justru lebih tinggi daripada kontrolnya. Peningkatan dosis radiasi sinar gamma EMS cenderung menghambat pertumbuhan tanaman $C$. zedoaria. Sejumlah tanaman mutan teridentifikasi pada generasi $\mathrm{vM}_{1}$ dan $\mathrm{vM}_{2}$ Mutan yang diamati terutama mutasi klorofil pada daun seperti albino, white streak atau daun variegata. Kondisi ini dikarenakan adanya penurunan kemampuan tumbuh sekumpulan sel pada daerah meristem akibat dari perubahan struktur DNA atau kerusakan DNA. Mutagenesis dengan iradiasi sinar gamma dapat mengakibatkan mutasi fenotipik yang berat karena mutasi yang terjadi menyebabkan delesi skala besar dan kadangkadang rekonstitusi kromosom (Matsukura et al., 2007; Vizir dan Mulligan, 1999; Naito et al., 2005). Kebanyakan mutan yang diinduksi sinar gamma menyebabkan delesi skala besar hingga $6 \mathrm{Mb}$ (Naito et al., 2005). Akan tetapi, dosis sinar gamma yang sedang dan rendah menyebabkan mutan yang berguna relatif tinggi dengan sifat-sifat daya hasil yang normal (Dumanovic et al., 1968). Walaupun mengalami delesi, tanaman masih bertahan hidup, akan tetapi, yang mengalami delesi skala besar dapat menyebabkan kematian (Vizir dan Mulligan, 1999).

Hasil penelitian ini menunjukkan terjadi efek rangsangan tumbuh oleh radiasi gamma. Pada konsentrasi rendah (300 rad), radiasi gamma mampu memacu peningkatan nilai karakter tanaman. Fenomena ini juga dilaporkan pada gandum yang menunjukkan bahwa dosis rendah radiasi gamma mempunyai pengaruh yang menstimulir terhadap karakter agronomis kultivar gandum pada generasi $\mathbf{M}_{1}$.

Perubahan terutama yang teramati pada profil RAPD yaitu muncul atau tidak munculnya pita DNA dengan berbagai variasi, dan intensitas. Pengaruh ini mungkin berkorelasi dengan perubahan struktur dalam DNA yang disebabkan oleh berbagai macam kerusakan DNA. Variasi dalam intensitas pita DNA dan hilangnya beberapa pita DNA mungkin berkorelasi dengan tingkat fotoproduk dalam DNA template setelah perlakuan radiasi, yang dapat menurunkan jumlah binding sites untuk Taq polymerase (Selvi et al., 2007). Penampilan pita DNA yang baru akibat induksi mutasi dapat dijelaskan sebagai akibat perubahan struktur DNA baik berupa patahan, transposisi atau delesi (Selvi et al., 2007). Irradiasi gamma dapat menyebabkan perubahan kimia, terlepasnya fosfat dan/atau basa pada kompleks DNA, yang mempengaruhi molekul DNA secara keseluruhan, bahkan apabila ada deoksiribosa yang terkena perubahan, akan menimbulkan kerusakan rantai molekul DNA (Ahnström, 1977).

\section{Kesimpulan dan Saran}

\section{Kesimpulan}

Induksi mutasi dengan sinar gamma pada C. zedoaria dapat dilakukan dengan dosis radiasi pada LD-50 yaitu dosis 813.82 rad. Keragaman genetik $C$. zedoaria hasil induksi radiasi dapat dideteksi dengan menggunakan marka RAPD. Dari 4 primer RAPD diperoleh 92 fragmen DNA yang berukuran dari $160 \mathrm{bp}$ hingga $2.6 \mathrm{~kb}$, dengan $71(98.61 \%)$ merupakan fragmen polimorfik. Hasil analisis menunjukkan bahwa nilai ketidaksamaan genetik untuk ke dua puluh sampel $C$. zedoaria hasil induksi berkisar dari $0.35-0.75$, lebih jauh lebih besar bila diibandingkan dengan koleksi $C$. zedoaria tanpa perlakuan induksi yang memiliki nilai ketidaksamaan genetik antara 0.02-0.07. Hasil ini mengindikasikan bahwa koleksi genotipe mutan $C$. zedoaria memiliki keragaman yang lebih luas dibandingkan koleksi $C$. zedoaria tanpa perlakuan induksi mutasi. 
Saran

Evaluasi karakter agronomis dan kandungan kimia sebaiknya dilakukan untuk mendapatkan genotipe mutan yang lebih baik.

\section{Ucapan Terima Kasih}

Penelitian ini didanai oleh Program DIPA Pusat Penelitian Biologi LIPI Tahun Anggaran 2005 dan 2006 di bawah KSK Bioprospekting Zingiberaceae Sebagai Immunomodulator.

\section{Daftar Pustaka}

Ahloowalia, B.S., Maluszynski, M. and Nichterlein, K. 2004. Global Impact of Mutation-Derived Varieties. Euphytica 135: 187-204.

Ahnström, G.R. 1977. Dalam Manual on Mutation Breeding. Technical Reports Series No 119. IAEA, Vienna.

Delaporta, S.L., Wood, J. and Hicks, J.B. 1983. A plant DNA Minipreparation. Version II. Plant Mol. Biol. Rep. 4: 19-21.

Dumanovic, J., Denic, M., Jovanovic, C. and Ehrenberg, L. 1968. Radiation-Induced Heritable Variation of Quantitative Characters in Wheat. Hereditas 62: 221-238.

Dunn, G. dan Everitt, B.S. 1982. An Introduction to Mathematical Taxonomy. Cambridge: Cambridge University Press.

Lee, Y.I., Lee, I.S. and Lim, Y.P. 2002. Variations in Sweetpotato Regenerates from Gamma-ray Irradiated Embryogenic Callus. J. Plant Biotechnol 4: 163-170.

Maluszynski, M., Nichterlein, K., van Zanten, L. and Ahloowalia, B.S. 2000. Officially Released Mutan Varieties-the FAO/IAEA database. Mutation Breeding Review 12: 1-84.

Matsukura, C., Yamaguchi, I., Inamura, M., Ban, Y., Kobayashi, Y., Yong-gen, Yin., Saito, T., Kuwata, C., Imanishi, S. and Nishimura, S. 2007. Generation of Gamma IrradiationInduced Mutan Lines of The Miniature Tomato (Solanum lycopersicum L.) Cultivar 'Micro-Tom'. Plant Biotechnology 24: 39-44.
Naito, K., Kusaba, M., Shikazono, N., Takano, T., Tanaka, A., Tanisaka, T. and Bishimura, M. 2005. Transmissible and Nontransmissibile Mutations Induced by $\gamma$-rays and Carbon Ions. Genetics 169: 881-889.

Poerba, Y.S. 2007. Identifikasi Genetik Curcuma zedoaria Hasil Induksi Mutasi. Laporan Teknik Pusat Penelitian Biologi - LIPI. Tidak diterbitkan.

Sangsiri, C., Sorajjapibub, W. and Sribives, P. 2005. Gamma Radiation Induced Mutation In Mungbean. Science Asia 31: 251-255.

Rohlf, F.J. 1997. NTSYS-pc. Numerical taxonomy and multivariate analysis. Version 2.0. Exeter Software. New York.

Schouten, H.J. and Jacobsen, E. 2007. Are Mutations In Genetically Modified Plants Dangerous? J. of Biomedicine and Biotechnology. Hindawi Publishing Corporation ArticleID82612, 2pages. oi:10.1155/2007/82612. Available on http://www.pubmedcentral.nih.gov/articlerend er. c ci ? artid $=2218926$.

Selvi, B.S., Ponnuswami, V. and Sumathi, T. 2007. Identification of DNA Polymorphism Induced by Gamma Rays Irradiation In Amla (Emblica officinalis Gaertn.) Grafts of V1M1 and V2M1 Generation. J. of Appl. Science Research 3 (12): 1933-1935.

Vizir, I.Y. and Mulligan, B.J. 1999. Genetics of GammaIrradiation-Induced Mutation in Arabidopsis Thaliana: Large Chromosomal Deleltions can be Resqued Through The Fertilization of Diploid Eggs. The American Genetic Association 90: 412-417.

Wardini, T.H. and Parkoso, B. 1999. Curcuma L. In: de Padua, L.S., Bunyapraphatsara, N. and Lemmens, R.H.M.J. (Eds). Plant Resources of South-East Asia No 12 (1). Medicinal and Poisonous Plants 1. Backhuys Publishers, Leiden, the Netherlands.

Williams, J.G., Kubelik, A.R., Livak, K.J., Rafalsky, J.A. and Tingev, S.V. 1990. DNA Polymorphism Amplified by Arbitrary Primers are Useful as Genetic Markers. Nucl. Acid Res. 18 (22): 6531-6535. 